\title{
Providing Sustainable Supports for Street Children in Nigeria: Stakeholders Challenges and the Policy Options Available
}

\author{
Joshua Oyeniyi Aransiola \\ Sociology and Anthropology Department, Obafemi Awolowo University, Ile-Ife, Nigeria \\ Email: aransiolajo@gmail.com, earansi@oauife.edu.ng
}

Received May $27^{\text {th }}, 2013$; revised June $26^{\text {th }}, 2013$; accepted July $3^{\text {rd }}, 2013$

\begin{abstract}
Copyright (C) 2013 Joshua Oyeniyi Aransiola. This is an open access article distributed under the Creative Commons Attribution License, which permits unrestricted use, distribution, and reproduction in any medium, provided the original work is properly cited.
\end{abstract}

\begin{abstract}
This article examines the limitations of all stakeholders in providing support for street children in Nigeria in the face of continuous increase in their number with a view to identify possible policy options in the light of inabilities of the stakeholders to adequately support the children. Qualitative research techniques were employed to collect the primary data from NGOs, community members and government agencies saddled with the responsibility of caring for the children. It was found that the stakeholders are incapable of addressing the problems of street children due to inadequate skills, lack of necessary facilities and stakeholders working in parallels among others. It emphasizes the need for collaboration among stakeholders to enjoy the benefit of synergy while there is also need to embark on capacity development for all the stakeholders in order to make meaningful progress and the situation of the street children improved in the country.
\end{abstract}

Keywords: Street Children; Social Supports; Child Rights

\section{Background}

Street children phenomenon is one of the gravest forms of child abuse raising concern at the global level in the past few decades. Bourdillon (2001) noted that when we see children neglected on the street, we should be worried about what this means for the future of our society. When we see young children fighting with knives, we should be worried about how violent they will be when they grow up. This has led to the increasing concern on how to provide adequate and sustainable supports to children working and/or living on the streets so that they can live better quality life and consequently contribute positively to the modern societies (Oloko, 1999; Scanlon, Tomkins, Lynch, \& Scanlon, 1998; UNICEF, 2012; Vasino, 1990).

According to Oloko (1999), Le Roux (1993) and Keen (1990), the factors which push children out of their homes vary from physical maltreatment and emotional problems, to be sent out of the home because of misdemeanors or family breakup and financial problems. UNFPA (2003) noted that increase migration to urban areas with associated problems like overcrowding, high unemployment, poverty, family dispersal and the impacts of HIV/AIDS have also contributed to increase in the number of street children in the recent times.

According to UNICEF (2002) and UNICEF (2007) the children's earliest experiences within the family and with other caregivers significantly influence the future course of their development. The way in which children develop determines whether they will make a net contribution or pose a huge cost to society over the course of their lives. Hence, as part of the efforts targeted at improving the situation of the children across different countries, the United Nations made the declaration of its Convention on the rights of the child 1989 which intended to prompt all state parties to take actions in addressing various problems confronting the children including street children phenomenon.

The African Union (formerly Oganisation of African Unity) (1999) also noted with concern that "the situation of most African children, remains critical due to the unique factors of their socio-economic, cultural, traditional and developmental circumstances, natural disasters, armed conflicts, exploitation and hunger, and on account of the child's physical and mental immaturity he/she needs special safeguards and care". It further recognizes the fact that "the child occupies a unique and privileged position in the African society and that for the full and harmonious development of his personality, the child should grow up in a family environment in an atmosphere of happiness, love and understanding". Thus, in an attempt to entrench the rights of the child in African societies, it declared a Charter on the Rights and Welfare of the Child 1999.

In Part 1 Article 1:1, the charter provided that member States of the Organization of African Unity (now African Unity) shall recognize the rights, freedoms and duties enshrined in the Charter and shall undertake to the necessary steps, in accordance with their Constitutional processes and with the provisions of the present Charter, to adopt such legislative or other measures as may be necessary to give effect to the provisions of this Charter" while it considers any human being below the age of 18 years as a child in Article 2:1. The Act therefore becomes a foundation, on which each country in Africa can build their legal instruments to guarantee the rights of the child. In response to this, 45 of the 53 African countries have signed and ratified the Act while various African countries have also en- 
acted laws to protect the rights of the Child. For instance, The Parliament of the Republic of Ghana (1998) enacted the Children's Act 560 1998, while The Parliament of Kenya (2001) enacted children's Act 8 in 2001 among others.

In line with these developments at the global and continental levels, the Federal Government of Nigeria (2003) promulgated a Child Rights Act in 2003 and there are many programmes emerging for the support of street children in Nigeria. These programmes include the provision of support in the area of feeding, clothing, housing, medical care and education. These events marked significant landmarks in ameliorating the problems of street children in the country.

In Nigeria, remand homes which is one of the units under the Social welfare department is the government agency dealing with children's problems and since the promulgation of the Nigerian Child Rights Acts 2003, the unit had been saddled with the responsibilities of addressing the needs of delinquent children including the street children in Nigeria. The unit has major offices in all the state capitals across the country with other offices in all major towns across the federation. There are also some NGOs and Civil Society organisations working to support the street children across many cities in Nigeria.

Despite all these efforts, the problem of street children seems unabated while it is becoming a permanent feature of the Nigerian societies. While efforts have been made to assess the challenges leading to increase in the number of street children (Aransiola, Bamiwuye, Akinyemi, \& Ikuteyijo, 2009; Fitzgibbon, 2003), the coping strategies of the children on the streets (Aransiola \& Agunbiade, 2009; Malindi \& Theron, 2010; Mizen \& Ofosu-Kusi, 2010; Oduro, 2012), the network of supports from street children's perspectives in Nigeria (Aransiola $\&$ Agunbiade, 2009; Faloore, 2009) and the attitudes of these children to the supports available for them (Aransiola \& Akinyemi, 2010), there has not been any effort to assess the problems and limitations confronting the stakeholders in providing supports for the children. Therefore the focus of this article is to assess the problems and limitations confronting the stakeholders in providing adequate, attractive and sustainable supports to the children with a view to identify workable and sustainable policy options. The objectives of this article therefore are to:

1) Examine the problems and challenges of all the stakeholders in providing support for street children in Nigeria; and

2) Identifying possible policy options in the light of inabilities of the stakeholders to adequately support the children.

\section{Methods}

This study was conducted in Lagos, Kaduna and Port Harcourt located in three different locations with different cultural orientations in Nigeria. The study was carried out in the cities of Lagos, Kaduna and Port Harcourt, which are three of the locations where street children are largely concentrated in $\mathrm{Ni}$ geria. The selected cities reflect the three main cultural diversities in Nigeria. Lagos is located in the south-western part of Nigeria on the narrow coastal plain of the Bight of Benin. Although, predominantly a Yoruba town, there is no other ethnic group in Nigeria that is not found in the city being the comercial heart of Nigeria and street children were physically present across different areas of the town.

Kaduna town was founded by the British in 1913 and later became the capital of Nigeria's former Northern Region from
1917 to 1967 . It is one of the most important political centre and important commercial centre in Northern Nigeria. There were so many quranic schools in the town just like a typical Northern Cities and street children from these schools and other sources were in their thousands on the street of the town. On the other hand, Port Harcourt, the capital of Rivers State, is the heart of the hydrocarbon industry and is responsible for a huge chunk of the nation's foreign exchange earnings. The town is Nigeria's second busiest seaport and has a busy international airport with regular links to all parts of the country and major cities of the world. It is the second largest commercial and industrial centre in Nigeria. Street children were also physically present in the town in their thousands and this has been constantly linked to the activities of the oil industries which have led to high poverty situation among its inhabitants.

In each of the selected cities, the government agency as represented by the Social Welfare Department, Non-Governmental Organisations, Other Civil Society Organizations (CSOs) and the Community members were focused as key stakeholders. Although the street children themselves are important key stakeholders, they were not focused in this study because their assessments and attitudes towards the supports networks available for them have been covered in earlier articles (Aransiola, Agunbiade, Ikuteyijo, \& Bamiwuye, 2009; Aransiola \& Akinyemi, 2010 respectively). Five Key Informant interviews were conducted in each of the cities selected for this study. These include two key government officials which were combined with observations of the facilities in the remand homes and three civil society organization leaders such as a church leader, an imam and a lawyer. In each study location, three (3) NGOs were purposively selected based on the services they render for the street children and semi-structured interview were conducted with at least one representative of each of the NGOs. The interview guide comprises of the NGOs' their mission mandate, reasons for supporting the streets children and the kinds of supports they provide for the street children. It also includes questions on the sources of their funding, the facilities they have and the problems they encounter in supporting the street children. Six Focus Group Discussions (FGDs) were conducted in each of the communities with different categories of community members namely; opinion leaders (male and female) (two), adult (male and female) (two), and youth (male and female) (two). Each FGD group will have eight to 12 participants. Each FGD included between 8 and 12 participants. The FGD participants were selected in the same neighbourhoods with the street children in order to ensure that data were collected from community members who have adequate knowledge about the children.

The qualitative data collected using Focus Group Discussions and in-depth interviews were analyzed using content analysis carried out with the help of the Text Base Beta Computer software. Data were carefully edited before importing it into the computer software. The data were then coded and sorted thematically according to the research objectives. The data from the content analysis were then presented using the ZY index tables.

\section{Characteristics of the Stakeholders}

The characteristics of the stakeholders included in this study are described here. The FGD participants' age across the three locations ranged between 25 and 75 years and included opinion 
leaders; males and females, adult; males and females, and youth; males and females (see Table 1). Each FGD group included both educated and uneducated members of the communities while there were more Muslims than Christians among the FGD participants in Kaduna as against more Christians than Muslims among the FGD participants in Lagos and Port Harcourt. This is expected because it is in line with the religion dominating in each region of the country.

The age category of the key informants was between 40 and 62 years out of which there were three government officials (one from each study location) from Social Welfare Department at least in the rank of Social welfare officers. There were also three church leaders, three Imam and three lawyers (1 from each study locations per category). In total, twelve (12) key informants were selected for this study (four in each location) out of which five were Muslims and seven were Christians. All the key informants had at least secondary school education.

The nine NGOs that were selected for this study are Millennium Hope Programme (MHP), Human Development Foundations in Nigeria (HDF) and Save the child Foundation (SCF), from Kaduna. In Lagos they include Christian Charity Organisation (CCO), Missionaries of Charity (Sisters of Mother Theresa) (MC) and Defence for children, International (DCI) while those included in Port Harcourt are The Adolescent Project (AP), Home for Street Children (HSC), SOCA Foundation, Nigeria (SOCAF). Most of the NGOs are membership NGOs while two were own by the wife of the State Governors of respective states. The sources of finance of the NGOs also revealed that most of them rely on donations from foundations, philanthropists, and personal resources. Only very few of these NGOs are assisted by the government and corporate organizations, while in most cases, they rely on international donour organizations.

\section{Results}

\section{Government Agencies Problems and Limitations in Supporting the Street Children}

The government agency as represented by the Social Welfare Department has a mandate to give succour to members of the community with social problems. It is assumed that the Social Welfare Department should have concerns for the Welfare of the street children. Data from key informants also revealed that the government through the Social Welfare Department has some programmes for the street children. The programmes include the provision of shelter, food, education, health services and vocational training among others, for the children with social problems including the street children. The extent to which the Department is fulfilling the mission mandate is however questionable. Evidence from this study revealed that most of the remand homes where the children were kept were very scanty with few children while the observation of the facilities revealed that the homes were not in good conditions to properly support the children. For instance, the environments of some of the homes were unhygienic and dirty while the homes were not well protected with mosquito nets. There were no constant supply of portable water and electricity while all of the facilities were short staffed (having 3 to 4 staff) and with little or no vocational training facilities.

In addition, some of the staff in the remind homes have not attended any training relating to handling of delinquent children while some have been serving with the department for more than 10 years without regular training. Most of the Officers in charge of the homes also complained of insufficient funding for the few children. Hence the children could not be given the best quality services as they ought to. It was also revealed that the practices in the homes were dominated by traditional punitive methods of correcting the children. It was therefore not surprising that the officers complained that some children do escape from the homes for street life. A key informant affirmed:

\begin{abstract}
"Some children sometimes run away from the centre (Remand home). When you look for them and bring them back they escape again. We are short staffed also. In this centre we are only three and the work is enormous for us". (Key Informant, Government Agency, Kaduna)
\end{abstract}

In the same vein a community member has this to say about the government agencies:

"The programmes of the Social Welfare Department are not well designed in a way to attract the street children. The programme emphasizes punitive measures as a means of rehabilitating the street children. They see Approved Schools as a prison yard. Hence, many street children usually run away from government approved schools. I think that, if the programmes are designed to be attractive, it will be more productive than the way it is now". (FGD with Opinion Leaders, Lagos)

\section{Non-Govermental Organisations (NGOs) and Other Civil Society Organisations' (CSOs) Challenges in Supporting the Street Children}

Over the years NGOs have been very active in developmental issues across different nations and they have been considered as active and important partners by development partners across the globe. According to Micheal (2002), "NGOs as one of the most visible sets of actors in the related fields of human development and human rights, can play a significant role in helping to achieve human security. NGOs are especially well

Table 1.

The focus groups involved in the study.

\begin{tabular}{cc}
\hline Males & Females \\
\hline Male opinion leaders, 55 - 65 years & Female opinion leaders, 45 - 60 years \\
(3 groups, 1 each in Kaduna, Lagos and Port Harcourt) & (3 groups, 1 each in Kaduna, Lagos and Port Harcourt) \\
Young males, 23 - 30 years & Young females, 22 - 32 years \\
(3 groups, 1 each in Kaduna, Lagos and Port Harcourt) & (3 groups, 1 each in Kaduna, Lagos and Port Harcourt) \\
Adult males 35 - 75 years & Adult females, 36 - 71 years \\
(3 groups, 1 each in Kaduna, Lagos and Port Harcourt) & (3 groups, 1each in Kaduna, Lagos and Port Harcourt) \\
\hline
\end{tabular}


suited to action for human security because of their size and reach, closeness to local populations, willingness to confront the status quo, and ability to address transnational threats through coalition-building". Hence, in addressing the problem of street children, the role of local NGOs cannot be over-emphasized. In this study, selected local NGOs were asked for the challenges confronting them in supporting the street children in Nigeria. Evidence from the study revealed that the NGOs do provide shelter, feeding, clothing, educational materials and scholarships for some children including street children. They however noted that in reality, the impact of these supports on the street children was minimal because of problems confronting their effective operations.

Apart from very few NGOs that exist in this sector, most of them were faced with lack of funds as Nigerian government rarely support them and they rely solely on personal resources, donations from willing individuals/organisations and occasional grant from international agencies. Most of the NGOs also had very poor infrastructures. In fact, many of them were faced with the problem of viability and sustainability as they were located in rented apartment contrary to the Nigerian government condition for their registration which mandates an NGO to have its own building. Most of the NGOs in this study did not fulfill this condition (see Table 2).

It was also evidenced in this study that most of the NGOs were poorly staffed with some having as few as 2 staff and others at most having 7 staff members. In addition to this, most of the staff (more than $90 \%$ ) did not have any previous training related to handling of delinquent children. Hence, they complained of little achievements especially in the area of rehabili- tation and re-integration of the children, which should be the main focus of any programme targeting the street children. For instance, only 3 of the NGOs claimed to have been able to successfully rehabilitate few street children while only 1 of them was able to re-integrate such children with their families (Table 3). An NGO official affirmed;

\begin{abstract}
"The kind of work we do is enormous and requires a lot of money. You know how much it could cost to maintain a street child, giving him/her food, shelter, clothing, education and so on and the resources is not forth coming as such. Also, if the resources are coming as it should, there is need for so many people to share the vision to assist them. So there is need for many more NGOs providing support for street children because the population is increasing every day". (NGO Official, Port Harcourt)
\end{abstract}

When other Civil Society Organizations such as the religious bodies were interviewed, it was evident that they also provide some assistance to the street children but the extent to which such assistance was satisfying the needs of the children could not be ascertained. This is partly because most of the assistances were rendered by individual members of such organisations in uncoordinated manner except in the case of one of such organisations which channeled the assistance through a NGO in their area. For instance, a key informant noted that:

"Arms giving is part of Islamic tenets and we preach it and practice it every Fridays after the usual Jumat service especially for the less privileged including the street children". (In-depth Interview with Imam, Kaduna)

Table 2.

Facilities of the NGOs.

\begin{tabular}{|c|c|c|c|c|c|c|c|c|c|}
\hline \multirow{2}{*}{ Facilities } & \multicolumn{3}{|c|}{ Kaduna } & \multicolumn{3}{|c|}{ Lagos } & \multicolumn{3}{|c|}{ Port Harcourt } \\
\hline & MHP & HDF & SCF & $\mathrm{CCO}$ & MC & DCI & $\mathrm{AP}$ & HSC & SOCAF \\
\hline Accommodation for street children & + & + & + & - & - & - & + & + & - \\
\hline Vocational training centre & + & - & + & - & + & - & + & + & - \\
\hline Own building/office complex & + & - & - & - & + & - & + & - & - \\
\hline Rented apartment & - & + & + & + & - & + & - & + & + \\
\hline
\end{tabular}

Note: $+=$ where the facilities exist; $-=$ where the facilities does not exist.

Table 3.

Achievements of the NGOs.

\begin{tabular}{|c|c|c|c|c|c|c|c|c|c|}
\hline & \multicolumn{3}{|c|}{ Kaduna } & \multicolumn{3}{|c|}{ Lagos } & \multicolumn{3}{|c|}{ Port Harcourt } \\
\hline & MHP & HDF & $\mathrm{SCF}$ & $\mathrm{CCO}$ & $\mathrm{MC}$ & DCI & $\mathrm{AP}$ & HSC & SOCAF \\
\hline Rehabilitation of street children & + & - & - & - & + & - & + & - & - \\
\hline Re-integrated some street children with families & - & - & - & - & + & - & - & - & - \\
\hline Provision of Shelter for street children & + & + & + & + & + & - & + & + & - \\
\hline Feeding of street children & + & + & + & + & + & - & + & + & + \\
\hline Sponsored street children's education & + & + & + & + & + & + & + & + & + \\
\hline Payment of hospital bills for street children & + & - & + & - & + & - & + & + & - \\
\hline
\end{tabular}

Note: $+=$ where the achievements were made; $-=$ where the achievements were not made. 
Whereas another key informant said that:

"In my church, we occasionally contribute money for the needy in the society including the street children and give such contribution to the NGOs supporting them but more importantly, we preach every time to our members on the importance of giving arms and I know some members who are actually doing it". (In-depth interview with Pastor, Lagos)

It was evidenced however that most of the assistance given to the street children were to satisfy their immediate needs to the neglect of more life impacting needs like education, health services and accommodation, while the extent to which this immediate needs were satisfied cannot even be ascertained.

\section{Community Members Supports for Street Children}

The community members are important stakeholders in resolving the problem of the street children because the street children phenomenon is a product of the society ills and the community members are the closest among all the stakeholders to these children. They interact with the children on daily basis and may be assumed to have a lot of information about these children. In this study therefore, efforts were made to understand the kind of assistance rendered to the street children by the community members and their limitations of supporting the children. Evidence from FGDs with community members show that there was a mixed feeling towards the street children at the community level. While some community members expressed that they do give some assistance to the street children, other are highly skeptical and have a feeling of apathy towards the children, yet some others are very careful on the type of assistance given as they believe that it could result to their conflict with security agents. For instance, the common assistance mentioned by the community members includes food, money, unused clothes and other unused materials. Concrete and other life impacting assistance such as accommodation, education and health care services are rarely or even not given at all. They further reiterated that many of those who pretend to give such assistance are only using the medium to further exploit the children. A participant expressed that:

"I pity the street children because many of them are victims of circumstances. I do give them some unused materials and food occasionally because they have no other option to live more quality life than they are living and their future is bleak". (FGD with Youth males, Kaduna)

While another participants said that:

"Although as a human being, when you see some of the children you are moved to give some assistance but again you must be careful the kind of assistance you give. If you accommodate the child, the police can charge you for abduction if any query should arise. If a street child is sick and in a dangerous situation that need quick intervention and you take him/her to hospital, you could be arrested if the sickness get worse or the child eventually died. The police might say that you are responsible for the harm or death of the child". (FGD with Adult Women, Lagos)

\section{Discussions and Policy Options}

This study examined the problems confronting the stake- holders in providing supports to the street children in Nigeria based on the spot observations and interviews with relevant key informants.

The Social Welfare Department as the government agency in the best position to help the street children in line with the Nigerian Child Rights Act 2003 could not do so due to series of problems confronting the unit. Apart from the fact that the Department had inadequate number of staff, they were also not equipped with adequate skills to help the children while the condition of the remand homes were also not conducive for the children. It was therefore not surprising that the children constantly escape back to the street. There is therefore the need to urgently increase the number of staff in the remand homes for better performance and provide up to date vocational training facilities. There is also the need for immediate and constant training of all the staff in the remand homes to better equip them on how to help the delinquent children especially the street children while new employees into the Department should be sent for training no matter of their academic qualifications. The practice in the remand homes visited was still been dominated by traditional punitive methods for correcting the children which is contrary to the spirit of the Convention for the Rights of the Child 1989 and the Nigerian Child Rights Act 2003. Nigerian government therefore needs to show more commitment to the international and local treaties by overhauling the Social welfare Department in line with changes at the global level. There is also the need to increase the allocation to this sector and institute adequate tracking methods to ensure that the money allocated are judiciously used. All these will enhance the condition of the remand homes and position them better to be able to help the children.

It is evident in this article that the NGOs working in the area of Child Rights and Welfare were very few in Nigeria while the few NGOs were also confronted with series of problems. These include lack of finance while they also have few staff, most of who were not trained on how to handle delinquent children. It is therefore important for these staff to be regularly trained for better performance. This calls for the need for international agencies funding these NGOs, to include capacity development training for the NGOs staff in a way to enhance their performances. It is also important for the NGOs to collaborate more with the other Civil Society Organisations in order to maximize the resources from them for better results. For instance, the opportunity of regular arms giving after Friday Jumat services in some mosques can be maximized by the NGOs. At present, the resources are given to the less privileged including street children directly by the individuals after the prayer, some of whom may not be able to use the resources judiciously especially, the children. If the NGOs can collaborate with the religious leaders to properly channel the resources, it will have more impact than the way the arms giving are presently been operated. Earlier studies affirm the importance of NGOs-community collaboration in intervention and developmental programmes (Barkin \& Bouchez, 2002; Ron, 1999). The NGO can incorporate members of the community and religious leaders as well as civil society organisations into their programmes targeting the street children for effective collaboration.

Although the community members as one of the stakeholders do assist the street children, the assistance given to these children is unreliable and in uncoordinated way while its extent of meeting the needs of the children could not be ascertained. Many community members are also skeptical of helping the 
street children because of the negative consequences. There is therefore the need for NGOs to work through the community leaders in enlightening the community members and working with them to support the street children. Since the registered NGOs cannot be harassed by the police or any security agents as they will deal with individual community members, it becomes important for the NGOs to work with these willing community members to maximize the resources and assistance from them for better results.

Finally, at present indications emerged that all the stakeholders supporting the street children in Nigeria are working in parallel with one another. It is therefore important for all the stakeholders to collaborate. The collaboration of the Social Welfare, NGOs and the community members is very important in the light of the fact that Nigeria continue to manifest the features of a weak state, and has been constantly not able to properly implement many beautifully designed programmes and policies of which the Nigerian Child Rights Act 2003 is one. This collaboration could allow the NGOs as well as community members to have active roles to play in the running of the Social Welfare Department especially the Remand home system where the street children are kept, thereby improving the quality of service and providing a medium for the community members who are skeptical of assisting the children to play active role in supporting them.

\section{Limitations}

This is a qualitative assessment of the stakeholders' challenges in supporting the street children in three major cities in Nigeria. Caution should be taken to generalize the findings on the entire country since the aim of qualitative research is not to generalize. It however gives useful insights into in-depth of the problems confronting the stakeholders. Research efforts are needed towards a more comprehensive survey of these stakeholders across significant numbers of urban cities in Nigeria since data from only three urban centres may not provide the most useful information for intervention. This article however point to areas

\section{Conclusion}

Based on the evidence in this paper it can be concluded that given the present condition of all the stakeholders supporting the street children in Nigeria, they are incapable of addressing the problems of street children in the country. There is therefore a need to change the strategy from working in parallel to collaborating together to enjoy the benefit of synergy while the international NGOs also need to embark on capacity development for all the stakeholders if they are to make meaningful progress and the situation of the street children reversed in the country.

\section{REFERENCES}

African Union (Formerly Oganisation of African Unity) (1999). African charter on the rights and welfare of the child 1999. Available at African Charter on the Rights and Welfare of the Child 1999.

Aransiola, J. O., \& Agunbiade, M. O. (2009). Coping strategies of street children in Nigeria. Journal of Social and Psychological Sciences. Oxford Mosaic Publications Limited, 2.

Aransiola, J. O., \& Akinyemi, A. I. (2010). Attitudes of street children to the network of supports available for them in Nigeria. IFE PsychologIA, 18. doi:10.4314/ifep.v18i1.51667

Aransiola, J. O., Bamiwuye, S. O., Akinyemi, A. I., \& Ikuteyijo, L. O. (2009). Proliferation of street children in Nigeria: Issues and challenges. Journal of Social Work, 9, 371-385. doi: $10.1177 / 1468017309342539$

Barkin, D., \& Bouchez, C. P. (2002). NGO-community collaboration for ecotourism: A strategy for sustainable regional development. Current Issues in Tourism, 5, 245-253. doi:10.1080/13683500208667921

Bourdillon (2001). The children on our streets. Reading for youth and childcare workers.

Faloore, O. O. (2009). Social networks and livelihood of street children in Ibadan, Nigeria. International Journal of Sociology and Anthropology, 1, 82-89.

Federal Government of Nigeria (2003). Nigerian child rights acts 2003 enacted by the national assembly of federal Republic of Nigeria.

Fitzgibbon, K. (2003). Modern-day slavery? African Security Review, 12, 81-89. doi:10.1080/10246029.2003.9627573

Keen, J. (1990). Dealing with street children. The Child Care Worker, 8 , 8-9.

Le Roux, J. (1993). Street children: A "man-made" phenomenon. Journal of Pedagogics, 16, 31-39.

Malindi, M. J., \& Theron, L. C. (2010). The hidden resilience of street youth. South African Journal of Psychology, 40, 318-326. doi: $10.1177 / 008124631004000310$

Micheal, S. (2002). The role of NGOs in human security. The Hauser Center for Nonprofit Organizations and The Kennedy School of Government, Harvard University, November 2002. Working Paper \#12, Submitted to the Commission on Human Security as background material.

http://www.hks.harvard.edu/hauser/PDF_XLS/workingpapers/workin gpaper_12.pdf

Mizen, P., \& Ofosu-Kusi, Y. (2010). Asking, giving, receiving: Friendship as survival strategy among Accra's street children. Childhood, 17, 441-454. doi:10.1177/0907568209350511

Oduro, G. Y. (2012). "Children of the street": Sexual citizenship and the unprotected lives of Ghanaian street youth. Comparative Education, 48, 41-56. doi:10.1080/03050068.2011.637762

Oloko, S. B. A. (1999). Child labour: The hidden workforce-Children domestic labour. The Progress of Nigerian Children, 48-51.

Ron, A. (1999). NGOs in community health insurance schemes: Examples from Guatemala and the Philippines. Social Science \& Medicine, 48, 939-950. doi:10.1016/S0277-9536(98)00394-3

Scanlon, J. T., Tomkins, A., Lynch, M. A., \& Scanlon, F. (1998). Street children in Latin America. Education and debate. BMJ, 316, 15961600. doi:10.1136/bmj.316.7144.1596

The Parliament of Kenya (2001). Kenya children's act 8 in 2001. http://www1.chr.up.ac.za/undp/domestic/docs/legislation_03.pdf

The Parliament of the Republic of Ghana (1998). Ghana child right act 560. http://mowacghana.net/download/childrens_act.pdf

UNFPA (2003). State of world population: Overview of adolescent life. http://www.unfpa.org/swp/swpmain.htm

UNICEF (2002). The state of the world's children. http://www.unicef.org/sowc02/

UNICEF (2007). At a glance: Nigeria. Digital diary; Nigerian street children tell their stories of life without security. $\mathrm{http}: / /$ www.unicef.org/people/nigeria_42282.htm

UNICEF (2012). The state of the World's children. http://www.unicef.org.uk/Latest/Publications/state-of-the-worlds-chil dren-2012/

Vasino, L. (1990). The socialization of street children: The development and transformation of identities. Sociological Studies of Child Development, 3, 139-161. 